\title{
アーク熔接法によるレール継目の接合に関する研究（第 $\mathbf{2}$ 報）*
}

\author{
一烍入レールの場合にっいて— \\ Welding of Rail Joints by Manual Arc Method (Report 2)* \\ - On the Case of Heat Treated Rail - \\ By S. Morita**, T. Itö** and T. Yonei**
}

守田点義** 伊藤悌二**米州 滉**

\begin{abstract}
This is to report about a welding experiment performod in joining heat treated rails with the hardness of 308-390 $\mathrm{Hv}$ and high abraision resitance.

The following are the results summarized with some comments :-

1) In joining heat treated rails by manual arc welding, satisfactory joint strength can be obtained, when the bottom and web are welded with low hydrogen type electrodes, following $90 \%$ of the top part welding by means of the same type electrodes, and then the head surface is built up about $10 \mathrm{~mm}$ deep with the intention of hardfacing. The joining strength does not change by hard surfacing.

2) For padding the employment of Mn Austenite type or Martensite type electrodes cannot be recommended, because of the cracks occurring at the fusion line between padding and base metals. We advise the use of low $\mathrm{Cr}$ steel type electrodes whose welding hardness is compatible with that of rail head and the welded metal is difficult to cause cracking.

3) By welding, the surface hardness of rail head is softened over the range of about $10 \mathrm{~mm}$ from the fusion line. Rails post heated for $30 \mathrm{~min}$. at $600^{\circ} \mathrm{C}$ immediately after welding tend to be softened down to about $250-280 \mathrm{Hv}$. over the heating zone, but the micro-structure of the point $50 \mathrm{~mm}$ apart from the fusion line is not remarkably changed, compared with the base metal structure.

4) As the result of passing trains for 80 days, it is recognized that the hardness of welding metal and softening zone of wheel side is inclined to increase by the cold working (train pass load; 38,000 ton/day) up to $2 \mathrm{~mm}$ depth under the head surface.

5) The abraision loss of the base metal, the post heated softening zone and the deposit metal are almost equivalent $2 \frac{1}{4}$ years after construction (train pass load $8,200,000$ ton/year, gradient $; 15 / 1000$, straight track of $348 \mathrm{~m}$ ), and the local abraision can't be observed.

It is therefore considered that this weldng procedure can be used practically.
\end{abstract}

\section{1 序言}

著者らは，先の第1 報りで主として普通レールの熔接継 目以関し破断試験の曲り強度に及ぼす噡接棒と施工法，予 熱抽よび後熱の効果について検討した. その結果，低水菜 系燃接棒を用い熔接の藸条件を適当飞選び，熔接の直後に $600^{\circ} \mathrm{C} 30$ 分間の短時間烧鈍を行党ば $50 \mathrm{~kg}$ P.S レールで 荷重 90 ton を越光，撓みは $45 \mathrm{~mm}$ 以上（破断エネルギ -3000 kg-m 以上）を常飞出しうる可能性があることを明

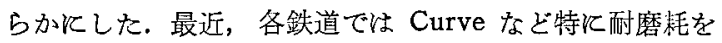
要求される䇢所烧入レール（頭部に焼入・焼尤しを行い 頭面硬さ 308〜390 Hv とした熱処理レール）を用いるこ とに観心を寄せているが, 焼入レールでは熔接継目部が頭

* 原稿受付 昭和33年 2 月26日（昭和33年度焀接学会 春季学術講演会飞和いて発表)

** 正員, 八幡製鉄所技術研究所 Member, Technical Research Institute, of Yawata Steel Works.
面硬度の低下により局部磨枆する懸念がある。

八幡製鉄所では昭30年11月に構内幹線の一部に揢接した 焼入レール（長さ $36 \mathrm{~m} ）$ を 4 本敷設した。著者らはこの

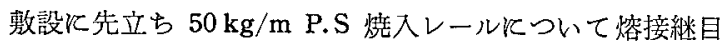
の破断試験や頭面便化拉よび敷設試験によるタイヤ踏面の 変化などについて実用化を目的とする諸実験で一応の成果 を得たので，ここに報告する。

\section{2 供試レール材と熔接方法および後熱}

供試レールは Table 1 亿示す成分の八橎製 $50 \mathrm{~kg}$ P.S 高周波烓入レールで，頭部は Photo. 1 のマク口應蝕組織 ならびそ顕微鏡組織に示すように頭面からかなりの範团は 熱処理による硬化層を有している。貲入深度は Fig. 10 断面略図 C扎よび $\mathrm{R}$ 位置で測定した硬度分布に示すように 頭面より $15 \mathrm{~mm}$ 厚さである.

熔接方法は，先の第 1 報で述べた普通レール継目の熔接 と全く同じ条件で行った. ただしレールの底・腹の全部と 
macro structure

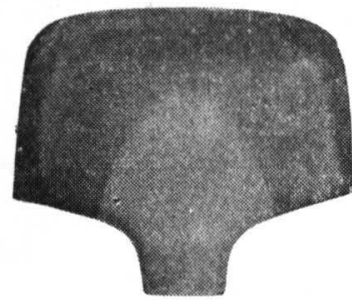

micro structure

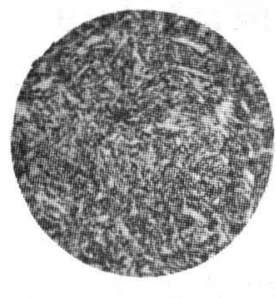

$\times 300$

Photo. 1 Macro and micro structure of heat treated rail

Table 1 Chemical Composition (\%) of Heat Treated Rails

\begin{tabular}{|c|c|c|c|c|c|}
\hline $\mathrm{C}$ & $\mathrm{Si}$ & $\mathrm{Mn}$ & $\mathrm{P}$ & $\mathrm{S}$ & $\mathrm{Cu}$ \\
\hline $0.66 \sim 0.69$ & $\mid \begin{array}{c}0.09 \sim \\
0.13\end{array}$ & $0.70 \sim 0.78$ & $\begin{array}{r}0.010 \sim \\
0.025\end{array}$ & $\begin{array}{r}0.022 \sim \\
0.028\end{array}$ & $0.17 \sim \sim_{0.20}$ \\
\hline
\end{tabular}

頭部の大部分を高張力鋼用の低水素系棒で地盛り熔接して 頭面の約 $10 \mathrm{~mm}$ 厚だけ Table. 2 飞行す熔着鋼成分と硬 度が得られる各種の熔接棒を用い. Photo. 2 飞示すよう 飞頭面硬化のための肉盛熔接を行った.

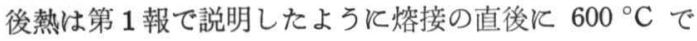
30分間保定する短時間焼鈍法を採用した.

\section{3 実験結果および考察}

1）破断試験と頭面硬化メタルの欠陷

前述のようとして20本（熔接のまま 7 本，後熱13本）

Table 2 Chemical Composition (\%) and Hardness of Hard Surfacing Deposit Metal

\begin{tabular}{c|c|c|c|c|c|c}
\hline \hline Metal type & $\mathrm{C}$ & $\mathrm{Mn}$ & $\mathrm{Si}$ & $\mathrm{Cr}$ & $\mathrm{Mo}$ & $\begin{array}{c}\text { Hardness } \\
(\mathrm{Hv})\end{array}$ \\
\hline Low Cr steel & 0.21 & 0.99 & $0.48 \sim 0.51$ & $1.22 \sim 1.35$ & - & $265 \sim 345$ \\
Mn Austenite steel & 1.10 & 11.0 & 0.6 & - & - & $450 \sim 550$ \\
Martensite steel & 1.00 & 0.80 & 0.8 & 4.0 & 0.7 & $550 \sim 600$ \\
Median Mn steel & 0.17 & 1.70 & 0.8 & - & - & $250 \sim 280$ \\
\hline
\end{tabular}

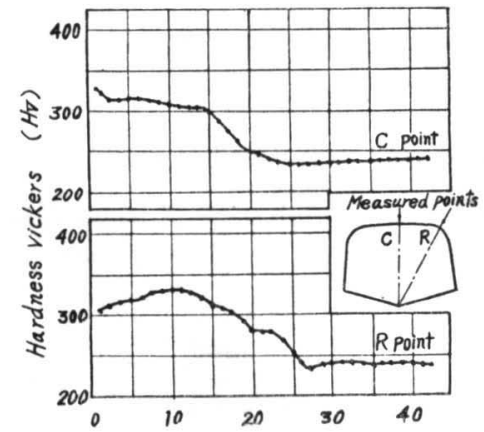

Distance from headsurface $(\mathrm{mm})$

Fig. 1 Hardness curve of rail head section

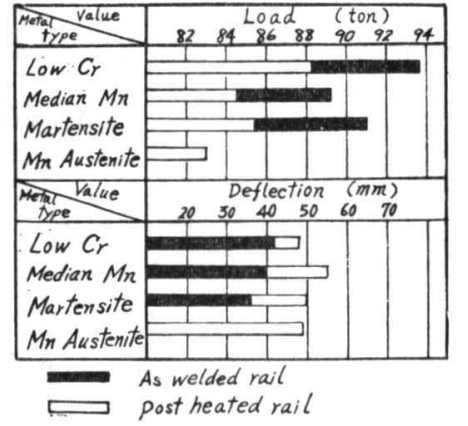

Fig. 2 Breaking strength of hard surfacing welded rail

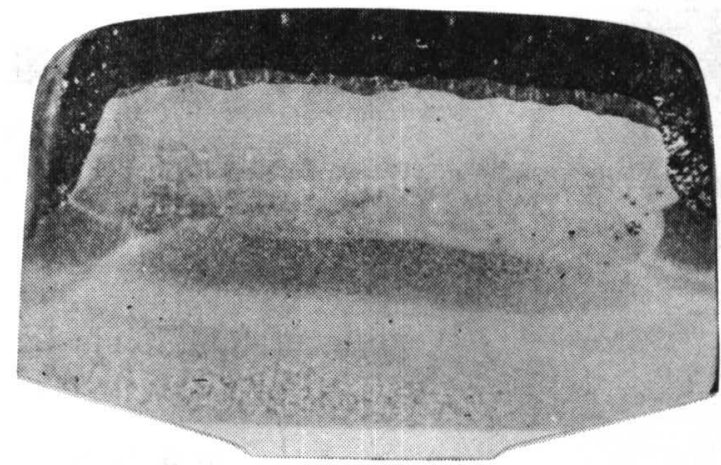

Photo. 2 An exsample of hard surfacing zone in welded rail head

の熔接レールを製作し熔接部はレール原形に仕上げた. こ の熔接レールの継目熔着鋼の頭面には Table 2 に示した 4 種類の硬化メタルを $2 \sim 4$ 本あて肉盛熔接した. 破断試 験は $1 \mathrm{~m}$ 支点で頭押しする方法で行い, その平均值を求 めて Fig. 2 そ示した.また, 頭部の破断面の範例を Photo. 3 に示した.

破断試験の結果をみると, 熔接ままのものが 89,200 t 93,800t で, 後熱したものは $83 \mathrm{t} \sim 88,400 \mathrm{t}$ である. 暁 みは熔接ままが $36 〜 42 \mathrm{~mm}$. 後熱すると $48 〜 55 \mathrm{~mm}$ とな って括り，この值はアーク熔接継目の強度として良好な成 績であると思う．頭面の硬化メタルは熔着量も少量である ためと思われるが破咪強度にあまり影響を及ぼすととはな く低水素系棒による地盛り熔接を良好に施工すれば 4 種類 の中のいられを用いても，破断強度に極端な優劣はないよ うであり，充分に実用できる值であ る.

しかし強度は充分であっても Phot. 3 飞見られるようと Mn オーステナ イト鋼やマルテンサイト鋼などでは硬 化メタルと地盛り熔着鋼との境界飞亀 裂を生じ剥離を起した。このような龟 裂の原因を考察すると，Mn オーステ ナイト鋼 (Photo. 4 a) は $260{ }^{\circ} \mathrm{C}$ 以 上の加熱によって粒界招よび粒内に Mn 鉄炭化物を析出し, 特飞 540 87 $0{ }^{\circ} \mathrm{C}$ では短時間で脆化する ${ }^{2}$ 傾向があ って，このためとその特性である靱性 を低下するまた，母材との境界部は Mn が稀釈されて融合部の近傍のオー ステナイトは不安定になり Photo. 4 (b) そ示すマルテンサイトなどを生ず る.この組織は脆弱なために母材と熔 着鋼の熱膨脹係数の相異により生ずる 収縮応力によって亀裂を生じ，ことに 


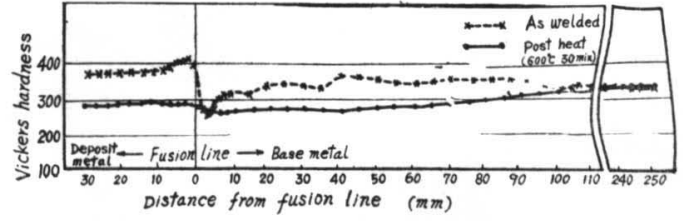

Fig. 3 Distribution of hardness in head surfaces of heat treated rails by manual arc welding

martensite steel Mn austenite steel

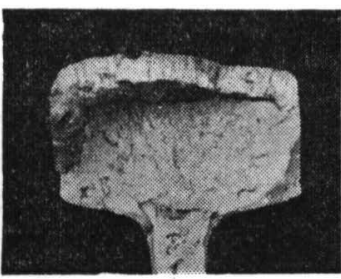

low $\mathrm{Cr}$ steel

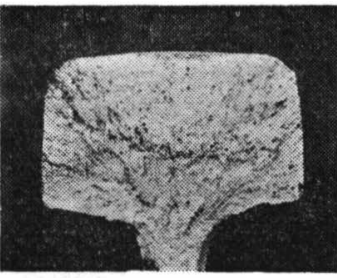

median Mn steel

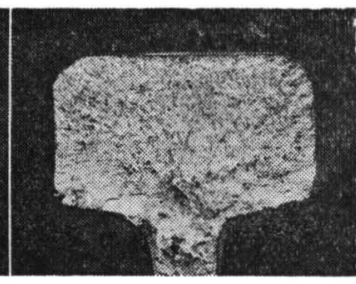

Photo. 3 Exsamples of breaking surface on fracture test of each hard surfacing rails

外力が作用するときは剝離現象を起すことになる. またマ ルテンサイト鋼の場合はマルテンサイト十残留オーステナ イト組織 (Photo. 4 c) であるが多層盛りの場合, 下層の 熔着鋼は加熱されて焼戻しされマルテンサイト (Photo. 4

d）を形成する.かかるマルテンサイトは脆弱であるう光 飞低温で急激な膨脹を起すために熔融線に亀裂を生じ剥離 の原因となるようである.

以上により, 破断強度は低水素系熔接棒で地盛り熔接を 行えば満足できる值のものが得られるので, 頭面硬化メタ
ルの欠陥がない熔接継目を得るとはレール頭面の硬度 (30 8〜390 Hv）と同程度が, やや低い硬度を有する低 $\mathrm{Cr}$ 鋼 を用いればよい。な拈中 Mn 錀では硬度が低く適当でな W.

2）レール頭部の硬度と組織とおよぼす熔接と後熱の影 響

硬度試験は熔接のままと後熱をした熔接レール材（低 Cr 鋼で頭面硬化) そついて, 頭面の中央線上の硬度変化 をビッカース硬度計で測定し，それぞれの硬度曲線として Fig. 3 に示した.

測定の結果では, 熔接ままのときは熔融線から $10 \mathrm{~mm}$ 範囲のレール頭面は硬度の低下が著しいが，熔融線よりの 距離が $20 \mathrm{~mm}$ 以上ではほとえど熔接の熱影響はないと見 なされる. これは Fig. 4 と示すような熔接時に挌ける頭 部の温度状況を熔融線から $5 \mathrm{~mm}$ 括き飞測定して求めた 最高温度曲線との関係を見れば, 熔融線から $10 \mathrm{~mm}$ 範囲 は $\mathrm{A}_{1}$ 変態以上の温度になるが, $20 \mathrm{~mm}$ 位置では $550^{\circ} \mathrm{C}$ であって, レール頭部の熱処理時の焼戻し温度にほぼ近い

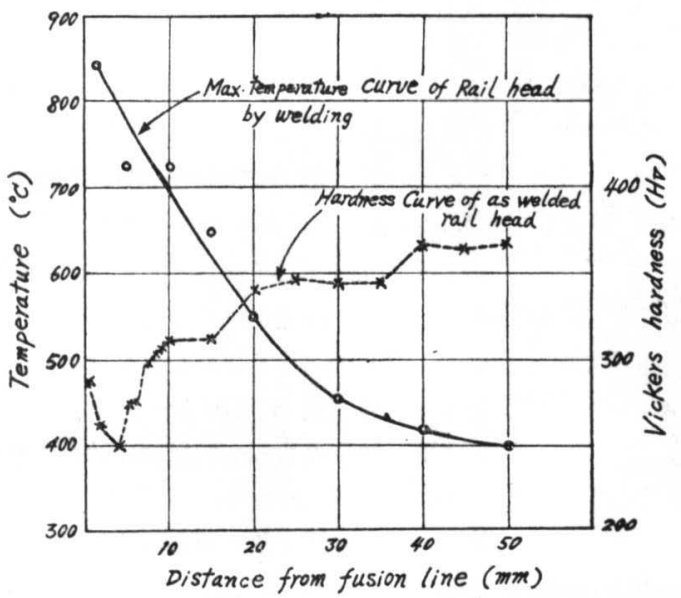

Fig. 4 Relation between max. temperature and hardness in as welded rail head (a)

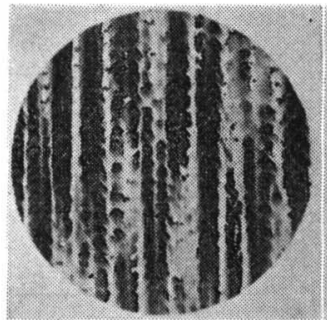

$\times 200$

normal structure (b )

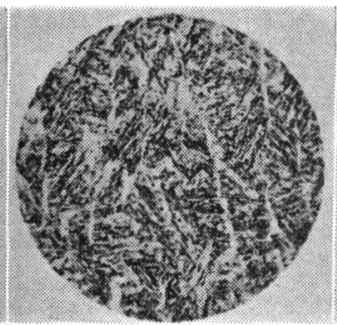

$\times 200$

structure obtained with manganese dilution (c)

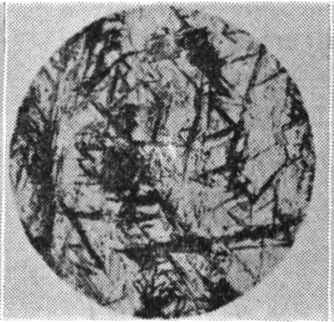

$\times 200$

normal structure (d)

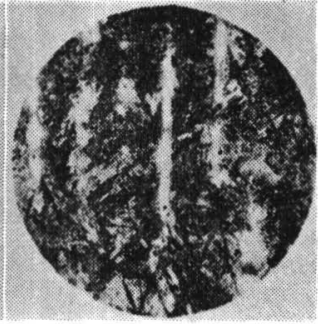

$\times 200$

tempered structure

Mn Austenite

Photo. 4 Micro structures of hard surfacing metal 


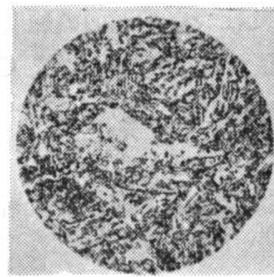

$\times 500$

(1) softing zone of base metal

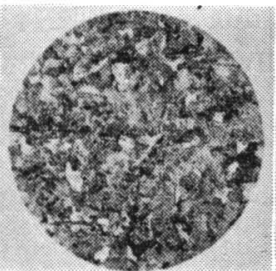

$\times 100$

(2) heat affected zone of base metal

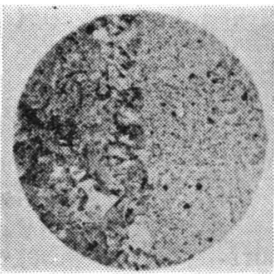

$\times 100$

(3) fusion line of hard surfacing metal and base metal

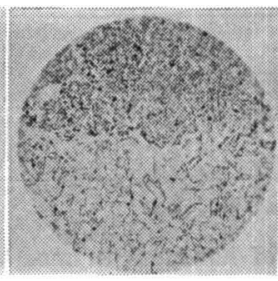

$\times 100$

(4) fusion line of hard surfacing metal and buttering metal

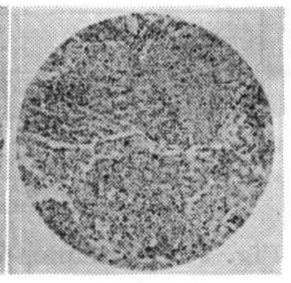

$\times 100$

(5) hard surfacing metal

Photo. 5 Micro structures of each zone in welded rail

程度の状態である．この試料を顕微鏡で観察した結果，熱 影響部 $(250 \mathrm{Hv})$ は結晶粒の小さなパーライト組織に変化 して抢り, 熔融線より $20 \mathrm{~mm}$ 位置では Photo. 1 のソル バイト組織と大差ないものであった.

熔融線から $100 \mathrm{~mm}$ 筑囲を後熱処理した熔接レールの 場合は, Fig. 3 の硬度曲線の傾向では後熱範囲が一様に軟 化して $270 〜 280 \mathrm{Hv}$ となっている. 熔融線から $50 \mathrm{~mm}$ 離れた位置のレール材組織をPhoto. 5〜1) と示したが, 軟化部は全般にこれと類似の組織で，カーバイトがかなり 粒状化したソルバイト組織である。 この組織は先のPhoto. 1 亿掲げたレール頭部の組織に比較して, それほど变化し ているようとは見兑ないが,レール頭部の熱処理時は約 500 ${ }^{\circ} \mathrm{C}$ の焼戻しであり，後熱温度がそれよりも約 $100{ }^{\circ} \mathrm{C}$ 高い ので, Photo. 1 の標準組織よりさら飞燒戻しされた組織 であることは間違いないが, 普通レールの䫓部がパーライ 卜組織で硬度も 250 2 $270 \mathrm{Hv}$ 程度であるのと比較して, 焼入レールの後熱軟化部は硬度が $270 \mathrm{Hv}$ 程度まで低く なっていてもソルバイト組織であるから耐磨耗性はそれは どととなわれていないことが同われる.

な招レールの熔接部近傍の母忉頭部㧍よび燃着鋼の顕微 鏡組織の観察を Fig. 5 飞示す(2)〜(5)の位置について行い Photo. 5(2)〜(5) 飞とれぞれ示した. すなわち，熱影響部 のレール材組織(2)はパーライト組織となって抢り結晶䊉も 比較的小さく、レールの標準組織に近い状態まで焼戻しさ

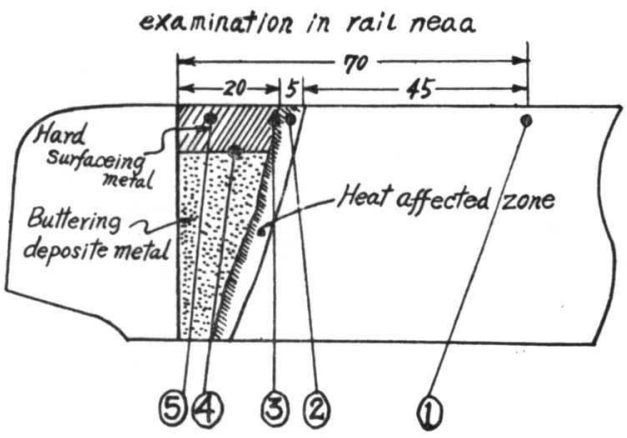

Fig. 5 Positions of micro-scophical examination in rail head
れている. 低 $\mathrm{Cr}$ 鋼 (頭面硬化メタル) とレール材との融 合部(3)愹融線が明膫飞現われていてレール材側の結晶粒 界にセメンタイトが析出して打り少々好ましくない融合状 態ではあるが，亀裂その他つ欠陷の発生は見られない，硬 化メタルと低水素系熔着鋼つ融合状態(4)は極めて良好であ り, 硬化メタル司は微小な粒状カーバイトの析出が見られ た.

以上のことから, 継目を熔接した場合, 熔接ままのもの は熔融線より $10 \mathrm{~mm}$ 範囲つレール頭面が熱影響により軟 化してパーライト組織 $(250 \mathrm{Hv}$ 程度) となるが, その他 飞問題点はなく, 後熱したものはその範囲全体が軟化して 270〜280 Hv となるが，ソルバイト組織であって焼入レ ール頭面つ標準組織飞比して極端な変化ななく, 耐磨耗性 ああまりそとなわれていないだろうと考光た.

3）タイヤ踏面に招ける熔着鋼刀加工硬化とレールの後 熱軟化部の再硬化

敷設試験用として長さ $12 \mathrm{~m}$ で中央に熔接継目を有する $50 \mathrm{~kg}$ 焼入レール（新品）を 1 本製作した. この熔接レー ルを直線水平区間に敷設し通過荷重 35,000 ton/day 速度 $20 \mathrm{~km} / \mathrm{hr}$ の条件で80日間飞亘って列車を通した．この間 ショアー硬度計とより硬化メタル（低 $\mathrm{Cr}$ 鋼）とレールの 後熱軟化部についてタイヤ踏面つ硬度変化を測定した結果 Fig. 6 の硬度曲線を得た. この曲線の傾向を見ると硬化

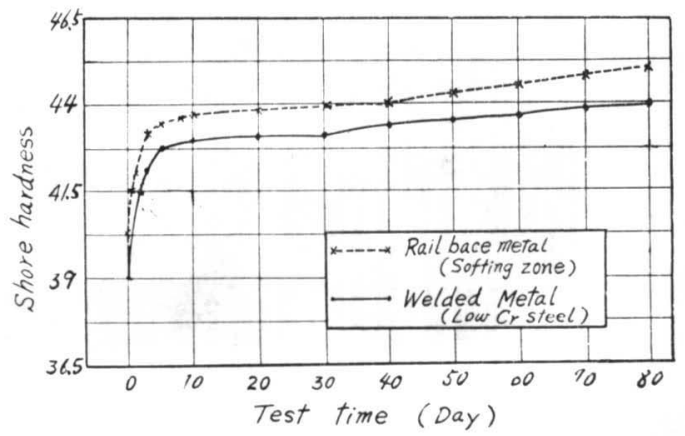

Fig. 6 Hardness changes of head surface in post-heated weld and base metal with the construction test. (load of train passes ; 35,000 ton/day) 

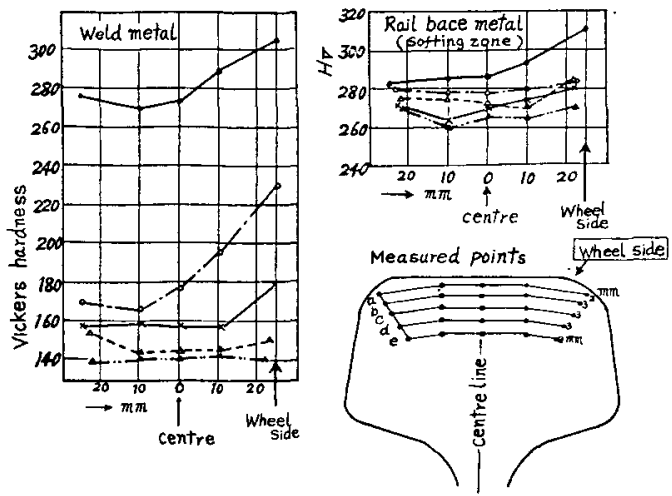

Fig. 7 Hardness of head section in weld and base metal after 80 day constructed

メタル括よびレール材とも敷設後の数日間に急滶に研化が 進み，以後慬からう硬化して80日を経たときは両者とも $44 \mathrm{Hs}(310 \mathrm{Hv})$ 以上にまで冷間加工をうけて硬度が上っ ている.

80日間の敖設試験を終った後，レールを取りはづして熔 着鋼の中心と熔融線より $50 \mathrm{~mm}$ 離れた位置のレール忉に ついて，それぞれの頭部の横断面に括ける硬度を Fig. 7 に示す要領で $\mathrm{a}$ 一 $\mathrm{e}$ 線つ位置を定め, 図解した䇴所を测定 した.

その結果は Fig. 7 亿示すように，椹断面の砬度は頭面 からの距離が浅い注ど，タイヤ踏面側の硬化が著しく，ま た，同じ樑さの位置ではタイヤ接触点の下が最も硬化する 傾向がある.なお，揢着鋼部は頭面より $8 \mathrm{~mm}$ 哚さのC 位置までは，かなり加工硬化の影響を受けているがレール 材の溃合はレールの硬度そのものが熔着鏈よりも高いため か，乙れほど著しい影響はなく加工便化に頭面より $2 \mathrm{~mm}$ 位である。

本実験は後熱した熔接継目のレール材軟化部や揢着鋼が 実際に列車を通した場合，短期間でどのくらい硬度変化を 生ずるかを確かめたのであるが，通過荷重や速度は本実験 の条件が必ずしも他の場合に当ては手らないので常にこの ような硬化の傾向になると断定できないが，敷設したレー ルでは冷間加工による硬化の程度に大小はあっても奏用し ているうちに熔着鎑や後熱軟化部の硬度が増してくること を考慮すれば後熱で乾化部を生ずることもとれ瓜ど，問題 視しなくてよいと思われる。

4）長期の敷設試験に拾ける撘接レールの磨耗量

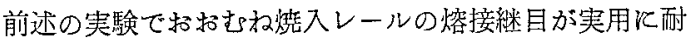
える見透しを得たので，36 m の燃接レールを 4 本製作し て棈内幹線 (年間飞 820 万 ton の通過量で速度 15 - 20 $\mathrm{km} / \mathrm{h}) の 350 \mathrm{~m}$ 直線区間, 15/1000 の上り勾配旉設し て荚用試験を続けているが，2 年3ケ月を経た後のレール 且材と後熱軟化部 (熔融線より $50 \mathrm{~mm}$ の位置) 括よび揢
Table 3 Abrasion Length of Welded Rail after Construction Test of $2,1 / 4$ Years

\begin{tabular}{|c|c|c|c|}
\hline & \multicolumn{2}{|c|}{ Rail } & \multirow{2}{*}{$\begin{array}{l}\text { Welded zone } \\
\left(\begin{array}{l}\text { Hard surfacing } \\
\text { metal }\end{array}\right.\end{array}$} \\
\hline & Base metal & $\begin{array}{c}\text { Post heated } \\
\text { zone }\end{array}$ & \\
\hline $\begin{array}{l}\text { Abrasion } \\
\text { length }\end{array}$ & $1.6 \mathrm{~mm}$ & $1.7 \mathrm{~mm}$ & $2.0 \mathrm{~mm}$ \\
\hline
\end{tabular}

着鋼部 (硬化メタル)のタイヤ踏面側の磨耗量を Fig. 8 に示す要領で测定した結果は Table 3 の值であっ た.

この結果からみる と, レール母材と後 熱軟化部は特に磨耗 量に差異はなく，熔 着鋼の頭面硬化メ夕 ルの部分はややレー ル材に比して磨耗し ていると見られる が，局部磨棵といえ るほどのものではな

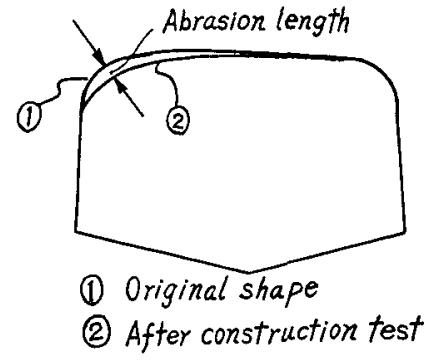

Fig. 8 Measuring method of abrasion loss
い、硬化メタル部がこのような結果になったのは, 使用し た低 $\mathrm{Cr}$ 鋼が Table 2 飞示した中の Cr $1.22 \%$ 程度の成 分であったので，その硬度は加工硬化しても $300 \mathrm{Hv}$ 以上 にはならなかったためで，これよりも $\mathrm{Cr} \%$ の高いものを 用いれば充分に防止できるむのである，直線区間と曲線区 間とではレール全体のタイヤ踏面の磨枆量には垶いを生ず るであろうか，たとえ曲線区間であっても，揢接継目の局 部磨耗は起らないだろうと云うことを本実験の結果から推 定できる.

な和敷設試験は今後も経続するのであるが現在の磨梩量 (年間 0.8〜1 mm 程度) からみて, 磨耗量 $8 \mathrm{~mm}$ 江達す るまでは，これから長年月は，このまま実用できる見透し である。

\section{4 結 論}

以上の奏験の結果を要約すれぼ,

1）アーク熔接法で焼入レールの継目燃接を行うとき は，高張力鋼用の低永素系熔接棒で底・腹の全部と頭部の 大部分を地盛り签接して頭面約 $10 \mathrm{~mm}$ 厚さだけ頭面硬化 の肉盛㷝接をすれば接手強度の良好なむのが得られる.

2）頭面硬化メタルに硬度の高い Mn オーステナイト 系またはマルテンサイト系熔接棒を用いて肉盛签接をした

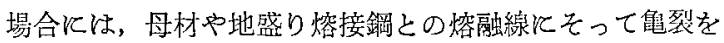
生じ㔀離するので，これらの特殊棒を用いるのはよくな W.

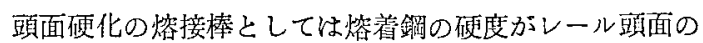


硬度 $(308$ - 390 Hv) と同程度で㟬裂を生じない低 $\mathrm{Cr}$ 鋼 加々い。

3）継目を熍接したレール材の頭面便度は，熔接ままで は熔融線から $10 \mathrm{~mm}$ 䇴国たけ $\mathrm{A}_{1}$ 变態温度を越光る熱影 響をうけて軟化 $(250 \mathrm{Hv})$ し，パーライト組織を生ずる

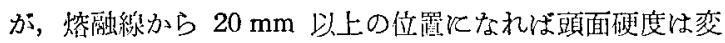
化がない。

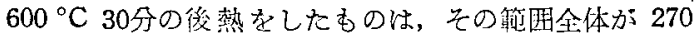
〜280 Hv 程度まで軟化する傾向があるが，組織㣿ソルバ イトであって母材の標準組織に比して，それほど変化はな いようである。

4）80日闍の政設試験（通荷荷重 38,000 ton/day）の

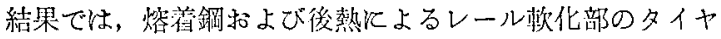
踏面の硬度は，冷間加工で $310 \mathrm{Hv}$ 以上飞㦈した。 また阘 者の頭部横䉼面の硬度は本輸侧，特にタイヤ接你点の下が 頭面より $2 \mathrm{~mm}$ 深さまで藷しく冷間加工の影響をうけて いる.

5）2 ケ年以上飞亘って列莗通過昌 820 万 ton/year, 速
度 $15 \sim 20 \mathrm{~km} / \mathrm{h}$ で 15/1000 の上り勾配の $350 \mathrm{~m}$ 直線区

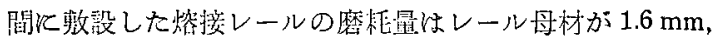
後蓺軟化部が $1.7 \mathrm{~mm}$ であって，とくに北状磨此飞变化は

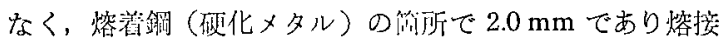

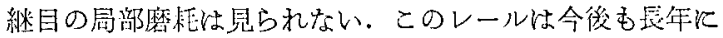
わたって实朋できる見透しである.

従って，継目を龽接した燃入レールは，熔接のままで用 いる埸合には喕面の磨耗で，ことさらに間題とする点なな

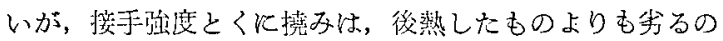
で管全性を考虑寸れ後熱を行った结うがよく，そのため

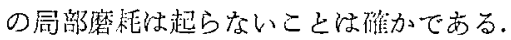

\section{文献}

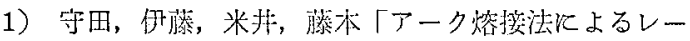

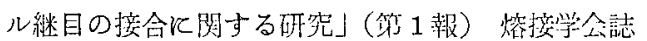
27 巻 2 목 (1958) 49

2) A. W.S., "Welding Handbook" p. 672 (Third edition).

\section{投稿規定拔萃}

1. 原稿の種類 熔接工学または技術に関する下記のもの，論文および報告 @揭載諭文に対する討諭 @坟術資 料，講義扔よび解説

3. 諭文および報告はすへて寄稿者の創意にもとづき，いまた他の学協会誌に揭载されたことのないものに限る.

5. 文体は和文（国語体）とし，なるべく内閣制定の当用漢字，現代仮名つかいによることまをた仮名は平仮名，数 字はアラビヤ数字，適当な邦語がない外国語は片仮名または原語で記すこと。

6. 諭文および報皆には必ず欧訳題目を附し，また欧文摘要（タイプ畫とする）をむ附すること。たがし摘要は800 語以内拓よび100語以内の 2 種類を添附のこと。

7. 諭文特よび報告は図表を加えて会誌 6 頁を超えないこと。やむをえず超過する埸合は卵刷費の一部として1頁に つき2000円を著者が負担するものとする。たよ゙し10頁を超えないこと．

8.図, 写真，表はなるべく少しく同一事項を図表雨方にて表わすことをさけ，次の要領に嗞うこと.

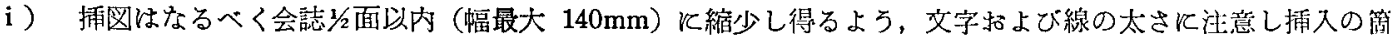
所をあらかじめ原稿诣定のこと.

ii）园表には必ずその内容を表示する簡単な見出しをつけ，欧交とすること.

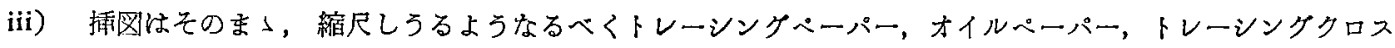
等に墨色で記入し図中文字も墨書すること.またインキ類あるいは彩色を施さないとと。

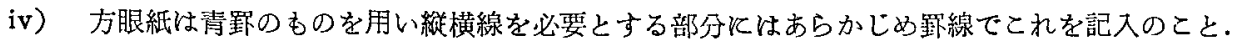

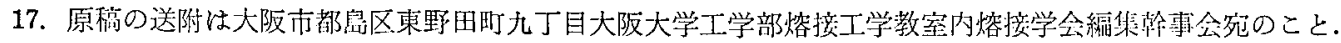

